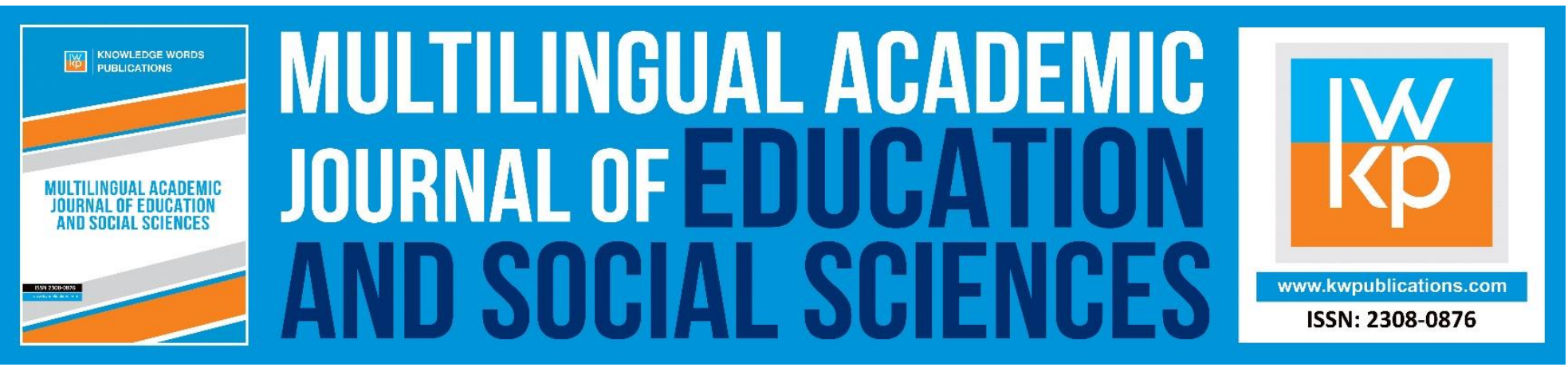

\title{
Development of Social Capital Measures in Indian Context
}

\author{
R. B. N. Sinha
}

To Link this Article: http://dx.doi.org/10.46886/MAJESS/v7-i1/5932

DOI: 10.46886/MAJESS/v7-i1/5932

Received: 10 April 2019, Revised: 19 May 2019, Accepted: 01 June 2019

Published Online: 19 June 2019

In-Text Citation: (Sinha, 2019)

To Cite this Article: Sinha, R. B. N. (2019). Development of Social Capital Measures in Indian Context. Multilingual Academic Journal of Education and Social Sciences, 7(1), 20-26.

\section{Copyright: (c) The Authors 2019}

Published by Knowledge Words Publications (www.kwpublications.com)

This article is published under the Creative Commons Attribution (CC BY 4.0) license. Anyone may reproduce, distribute, translate and create derivative works of this article (for both commercial and non-commercial purposes), subject to full attribution to the original publication and authors. The full terms of this license may be seen at: http://creativecommons.org/licences/by/4.0/legalcode

Vol. 7, No. 1, 2019, Pg. 20 - 26

Full Terms \& Conditions of access and use can be found at https://kwpublications.com/pages/detail/publication-ethics 


\title{
Development of Social Capital Measures in Indian Context
}

\author{
R. B. N. Sinha \\ Professor of Psychology, B.S. College, Danapur, Patliputra University, Patna \& Honorary Faculty, \\ ASSERT Institute of Management Studies, Patna
}

\begin{abstract}
Four hundred villagers were participated in the present study to develop a tool for the measurement of social capital. An exploratory factor analysis was conducted to identify dimensions of social capital. A principle component analysis was employed on the 33 items with orthogonal rotation on the criteria that eigenvalue should not be less than one and the factor must have acceptable reliability. Five factors such as social cohesiveness, cooperation, trust, acceptance of system and selfishness were found reliable and ranged from .69 to .90. The application of the tool will certainly facilitate research in assessing the role of social capital in affecting people's behavior in rural setting.
\end{abstract}

Keywords: Factor Analysis, Social Cohesiveness, Trust.

\section{Introduction}

The concept of social capital has gained tremendous progress over the past 25 years. Social capital has been studied on both the individual (micro) and collective (macro) level. Some investigators (Coleman, 1990; Putnam, 1995) elaborated theories specifically on the macro level where social capital is seen as a collectively produced and own entity from which the whole community may benefit. Coleman (1988) defines three forms of social capital-norms, information channels and collective obligations and expectations that operate through, and are facilitated by relational networks. Putnam (2000) focuses on trust, norms and networks and emphasizes the central role of civic engagement in a broad range of associations that can facilitate collective actions. Other investigators (Bourdieu, 1980, Flab, 2002; Lin, 1991, 2001) focused on social capital as an addition pool of resources at the individual which may be helpful for the individual's goal attainment. For, example, Coleman (1990) draws a map of social relation in which individuals are nodes, and social capital is represented as line uniting them. The more lines connect to an individual, the higher is the individual's level of social capital. Lin (2001) defined social capital as 'resources embedded in a social structure that are accessed and/or mobilized in purposive actions. The World Bank focuses on social cohesion and describes it as the internal social and 
MULTILINGUAL ACADEMIC JOURNAL OF EDUCATION AND SOCIAL SCIENCES

Vol. 7 No. 1, 2019, E-ISSN: 2308-0876 @ 2019 KWP

cultural coherence of society, the norms and values that govern interactions among people, and the institutions in which they are embedded (Grootaert, 1988).

As far as the measure of social capital is concerned, Collier (2002) contended that it is very difficult to measure social capital directly as the construct is abstract and subjective. However, other researchers (Grootaert \& Van Bastalaer, 2002; Onxy \& Bullan, 2002) argued that it is possible to measure both social capital and its impact. The purpose of the present paper is to develop a tool for the measurement of social capital with a focus on application for villagers. The key aspects of social capital, we concentrate on some dimensions of relationship orientation such as cooperation, trust and involvement in voluntary organization at village level.

\section{Method}

\section{Sample}

The sample comprised of 400 household respondents drawn from four villages of East Champaran and Patna district of Bihar (India). All the four villages, a sample of 100 household from each village were randomly selected. The mean-age of respondents was 40.30 $(S D=13.13 .57)$ years. Ninety per cent respondents were reported that they were not member of any religious organization. However, ninety-nine per cent respondents were reported to have their involvement in social activities such as marriage, social rituals etc. The respondents were interviewed with the help of a questionnaire. Sample statements were as follows: (i) do you trust the villagers? (ii) Is there brotherhood among the villagers?

\section{Social Capital Scale}

As social capital is hypothesized to be a multi-dimensional construct, it was proper to develop a number of factors that measured different dimension of social capital. Initially, a questionnaire of 50 items were selected to measure the different dimensions of social capital of the people participated in the present study. Seventeen items were dropped on the basis of item analysis. Most of the items were positively worded and responses were measured on a 5-point Likert scale from 1 (not at all) to 5 (to a great extent).

Before, applying to factor analysis a Kaise-Meyer-Olkin (KMO) measure of sampling adequacy test has been employed. KMO test examines whether the number of observations in the dataset are enough for applying factor analysis or not. A KMO value of more than .60 is considered satisfactory that means the number of observation in the dataset is sufficient for factor analysis. In the present study, the result of KMO is .91 that indicates the sample size is adequate and factor analysis can be applied. The Bartlett's test of sphericity, the $p$ value of the Chi-Square $\left(\chi^{2}=6032.21, d f=528, p<.001\right)$ test is found to be significant that shows there exists significant correlations between the different pairs of variables. Therefore, factor analysis may be useful for reducing the number of variables. Finally, thirty-three items were factor analyzed using Principal Component Analysis (PCA) with orthogonal rotation varimax solution on the criteria that Eigenvalue should not be less than 1 and the factor must have acceptable reliability (alpha coefficient > .60). Factor analysis is a technique for simplifying a data set. The aim of the method is to reduce the dimensionality of multivariate data while preserving as much of the relevant information as possible. Varimax is one of the methods of orthogonal rotation which attempts to maximize the dispersion of loading within the factors. An initial analysis (SPSS-17 version) was run to obtain Eigenvalue for each factor of the data. The most commonly used 
MULTILINGUAL ACADEMIC JOURNAL OF EDUCATION AND SOCIAL SCIENCES

Vol. 7 No. 1, 2019, E-ISSN: 2308-0876 @ 2019 KWP

technique is the latent root criterion. This technique is simple to apply to either component analysis or common factor analysis. The rationale for the latent root criterion is that any individual factor should account for the variance of at least a single variable if it is to be retained for interpretation. In component analysis, each variable contributes a value of 1 to the total eigenvalue. Thus, only the factors having latent root or eigenvalue greater than 1 is considered significant. Kaiser's (1960) rule was also followed to determine which factors were more eligible for interpretation because this rule requires that a given factor is capable of explaining at least the equivalent of one variable's variance. Using this rule, five factors had eigenvalue over Kaiser's criterion of 1 . This criterion is based on the idea that the eigenvalue represents the amount of variation explained by a factor and that an eigenvalue of 1 represents a substantial amount of variation. This eigenvalue-greater-than-one rule, also known as K1 (Kaiser, 1958) was implemented to ascertain an appropriate number of factors to retain. Two items such as, "Are majority of the villagers engaged in serving their own vested interest", and "Do the villagers take care of security arrangement on their own" were eliminated because they did not contribute to a simple factor structure and failed to meet a minimum criteria of having factor loading of .30 or above. Two items namely, "Do villagers use laws to dominate over poor people", and "Do villagers take care of security arrangement on their own" have been reversed in the final analysis of factor analysis as they have negative loading. The purpose of reverse scoring is to prevent a cancelling out of variables with positive and negative loadings.

The summary of exploratory factor analysis results along with high loading items, mean, standard deviation and variance explained by the factors has been presented in Table 1.

Table 1. Exploratory Factor Analysis Results for Social Capital Questionnaires ( $N=400)$

Factor 1-Social cohesiveness $(N=13, M=52.76, S D=7.96$, rii $=.90, V=29.70$, Eigenvalue $=9.80$ )

\begin{tabular}{lllll}
\hline $\mathbf{S . N}$ & Items & Loadin & $\mathbf{M e a}$ & SD \\
. & & $\mathbf{g}$ & $\mathbf{n}$ & \\
6 & Do people show unity during marriage ceremony? & .86 & 4.57 & .78 \\
9 & Do villagers often participate in social work (i.e. marriage etc.) in & .78 & 4.62 & .75 \\
& the village? & & & \\
12 & Do villagers take part in religious activities of the village? & .72 & 4.54 & .76 \\
4 & Are villagers ready to render support at time of need? & .70 & 4.13 & .95 \\
11 & Do villagers help each other in case of crisis situation? & .69 & 4.02 & .91 \\
5 & Are you feeling proud of your village people? & .67 & 4.38 & .88 \\
16 & Do the villagers take advice of elders? & .55 & 4.00 & 1.00 \\
29 & Are villagers homogeneous? & .59 & 3.76 & .93 \\
30 & Has your village developed? & .49 & 4.24 & .86 \\
26 & Do you believe in law and order of your village? & .49 & 4.12 & 1.00 \\
19 & Do villagers share their ideas? & .43 & 3.44 & .90 \\
31 & Do villagers respect each other? & .41 & 3.85 & 1.06 \\
28 & Do villagers share their individual problems with one another? & .32 & 3.12 & .99
\end{tabular}

Factor 2- Cooperation $(N=5, M=18.06, S D=3.79$, rii $=.81, V=8.80$, Eigenvalue $=2.90$ ) 
MULTILINGUAL ACADEMIC JOURNAL OF EDUCATION AND SOCIAL SCIENCES

Vol. 7 No. 1, 2019, E-ISSN: 2308-0876 @ 2019 KWP

14 Do villagers borrow money and other items among themselves? $\quad .70$

$3.80 \quad 1.03$

13 Does the unity exist in your village among upper and lower castes? 68

3.63 .96

22 Do villagers take part in 'Gram Shaba'?

.68

3.041 .09

25 Is there unity in your village?

.51

$4.00 \quad 1.08$

17

Do villagers resolve village problems among themselves?

.36

$3.58 \quad .82$

Factor 3- Trust $(N=3, M=10.27, S D=2.58$, rii=.82, $V=7.12$, Eigenvalue $=2.35)$

1 Do you trust the villagers? $\quad .82$

$3.20 \quad 1.02$

10 Do villagers often participate in social work (i.e. marriage etc.) in .75

3.44 .98 the village?

2 Is there brotherhood among the villagers?

.56

$3.63 \quad 1.00$

Factor 4-Acceptance of system $(N=4, M=17.14, S D=2.90$, rii= .62, $V=4.56$, Eigenvalue=1.51)

21 Do villagers take active part in general elections?

$\begin{array}{lll}.80 & 4.79 \quad .58\end{array}$

32 Do villagers take care of security arrangements on their own?

$-.65$

$4.17 \quad 1.24$

23

Do villagers trust in government programme and schemes?

.59

$4.20 \quad 1.10$

24

Do villagers use laws to dominate over poor people?

$-.50$

3.98

1.19

Factor 5- Selfishness ( $N=6, M=21.44, S D=3.04$, rii $=.69, V=3.79$, Eigenvalue= 1.25)

18 Do villagers look their individual interest even in collective work? $\quad .74 \quad 3.51 \quad .79$

$\begin{array}{lllll}15 & \text { Are villagers involved in demoralizing each others? } & .69 & 3.78 & .82\end{array}$

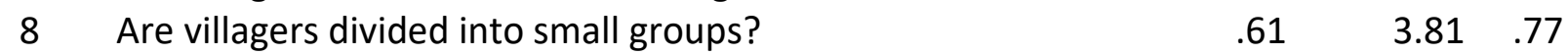

20 Do villagers distrust each other? $\quad .46 \quad 3.19 \quad .90$

$\begin{array}{lllll}27 & \text { Do villagers indulge in their own interest? } & .34 & 3.57 & .82\end{array}$

$\begin{array}{llllll}7 & \text { Do villagers take part in meetings only to fulfill their own interest? } & .33 & & 3.56 & .77\end{array}$

Table 1 reports the factor loadings after rotation and five factors were extracted. A factor loading represents the correlation between an original variable and its factor. The varimax rotation method was used to perform orthogonal rotation to eliminate items with factor loading $<.30$. The squared loading is the amount of variable's total variance accounted for by the factor. Thus, a .30 loading translates to approximately 10 per cent explanation and a .50 loading denotes that 25 per cent of the variance is accounted for by the factor. The rationale behind selection of factor loadings of .30 and above as the sample size is 400 participants.

\section{Social Cohesiveness}

It is also clear from Table 1 that 13 items such as 'people show unity during marriage ceremony', 'villagers often participate in social work in the village', 'villagers take part in religious activities of the village', 'villagers are ready to render support at time of need', 'villagers help each other in case of crisis situation', 'you feel proud of your village people', 'villagers take advice of elders', 'villagers are homogenous', 'your village has developed', 'you have faith in law and order 
MULTILINGUAL ACADEMIC JOURNAL OF EDUCATION AND SOCIAL SCIENCES

Vol. 7 No. 1, 2019, E-ISSN: 2308-0876 @ 2019 KWP

situation of your village', 'villagers share their ideas', 'villagers respect each other' and 'villagers share their individual problems with one another' were loaded on Factor I which was given the name, Social cohesiveness. This factor explained 29.70 per cent of the common variance and also showed high reliability ( $r i i=.90)$.

\section{Cooperation}

The items on Factor II, such as 'villagers borrow money and other items among themselves', 'unity exists in your village among upper and lower castes', 'villagers take part in Gram Shabha', 'unity in your village', 'villagers resolve village problems among themselves' were labeled as Cooperation. This factor explained 8.80 per cent of the common variance and also showed high reliability (rii= .81).

\section{Trust}

The items loaded on Factor III, such as, 'you trust the villagers', 'villagers often participate in social work', 'brotherhood among the villagers' were considered as a factor, Trust. This factor showed 7.12 per cent of the common variance and also reported high reliability (rii=.82).

\section{Acceptance of System}

The four items loaded on Factor IV such as 'villagers take active part in general election', 'villagers take care of security arrangements on their own', 'villagers trust in government programme and schemes', and 'villagers use laws to dominate over poor people', were addressed as a factor, Acceptance of system. This factor explained 4.56 per cent of the common variance and showed high reliability ( $r i i=.62)$.

\section{Selfishness}

The six items loaded on Factor $V$ such as, 'villagers look at their individual interest even in collective work', 'villagers are involved in demoralizing each other', 'villagers are divided into small groups', 'villagers distrust each other', 'villagers indulge in their own interest', 'villagers take part in meetings only to fulfill their own interest' were labeled as a factor Selfishness. This factor explained 3.79 per cent of the common variance and also showed high reliability (rii=.69). The total eigenvalues represent the total amount of variance extracted by the factor solution.

\section{Discussion}

The results demonstrated that social capital scale showed sound psychometric properties with a clear five factors structure and acceptable reliabilities in all subscales. Reliabilities analyses using Cronbach's alpha was employed for each of the subscales in the instrument utilized by using SPSS 17 version. According to (Tabachnick \& Fidell, 2007) the internal consistency reliability estimates above .70 is acceptable. The subscales of social capital ranged from .69 to .90. The test- retest of the instrument was not assessed. The derived five factors such as social cohesiveness, cooperation, trust, acceptance of system and selfishness supported the previous findings of Putnam (2000) and Woolcock (1999) that social capital is not a single entity rather a multidimensional construct. It describes circumstances in which individuals can use membership in groups and networks to secure benefits (Sobel, 2002). The factor of a single variable was found 
MULTILINGUAL ACADEMIC JOURNAL OF EDUCATION AND SOCIAL SCIENCES

Vol. 7 No. 1, 2019, E-ISSN: 2308-0876 @ 2019 KWP

high (more than .70) which indicated the convergent validity in the structure of factors and variables. Finally, the application of the tool will certainly facilitate research in assessing the role of social capital in affecting people's behavior in rural setting.

\section{References}

Cattell, R. B. (1966). The Screen Test for the Number of Factors. Multivariate Behavioral Research, 1, 245-276.

Coleman, J. C. (1988). Social capital in the creation of human capital. American Journal of Sociology, 94, 95-120.

Coleman, J. C. (1990). Foundations of Social Theory, Cambridge, Mass: Harvard University Press.

Collier, P. (2002). Social capital and poverty: a microeconomic approach. In The Role of Social Capital in Development, Thierry Van Bastelaer (Ed.), pp.19-41, Melbourne: Cambridge University Press.

Grootaert, C. (1998). Social Capital: The Missing Link? Social Capital Working Paper 3. The World Bank: Washington DC.

Grootaert, C., \& Van Bastelaer, T. (2002). Conclusion: Measuring Impact and Drawing Policy Implications. In the Role of Social Capital in Development, Thierry Van Bastelaer (Ed.), pp. 34-350, Melbourne: Cambridge University Press.

Kaiser, H. F. (1958). The variance criterion for analytic rotation in factor analysis. Psychometrika, 23, 182-200.

Kaiser, H. F. (1960). The application of electronic computers to factor analysis. Educational and Psychological Measurement, 20, 141-151.

Lin, N. (1999). 'Building a network theory of social capital' Connections, 22: 28-51.

Lin, N. (2001). Social Capital: a theory of social structure and action. Cambridge: Cambridge University Press.

Onyx, J., \& Bullen, P. (2002). "Sources of Social Capital". In Ian Winter (Ed.) Social Capital and Public Policy in Australia, pp. 105-135, Melbourne: National Library of Australia.

Pearson, K. (1901). On Lines and Planes of Closet Fit to Systems of Points in Space. Philosophical Magazine, Series 6, 2 (11), 559-572.

Putnam, R. D. (2000). Bowling Alone: The Collapse and Revival of American Community. New York, Simon and Schuster.

Sobel, J. (2002). "Can We Trust Social Capital?" Journal of Economic Literature, 11, 139-54.

Tabachnick, B. G., \& Fidell, L. S. (2007). Using Multivariate Statistics (5 $5^{\text {th }}$ Ed.). Boston, MA: Pearson Education, Inc.

Woolcock, M. (1999). Social Capital and Economic Development: Towards a theoretical synthesis and policy framework. Theory and Society, 27, 151-208. 